\title{
Spatial Scaling of Prevalence and Population Variation in Three Grassland Sparrows
}

Author(s): L. Lynnette Dornak, Narayani Barve and A. Townsend Peterson

Source: The Condor, 115(1):186-197. 2013.

Published By: Cooper Ornithological Society

URL: http://www.bioone.org/doi/full/10.1525/cond.2013.120055

BioOne (www.bioone.org) is a nonprofit, online aggregation of core research in the biological, ecological, and environmental sciences. BioOne provides a sustainable online platform for over 170 journals and books published by nonprofit societies, associations, museums, institutions, and presses.

Your use of this PDF, the BioOne Web site, and all posted and associated content indicates your acceptance of BioOne's Terms of Use, available at www.bioone.org/page/terms_of_use.

Usage of BioOne content is strictly limited to personal, educational, and non-commercial use. Commercial inquiries or rights and permissions requests should be directed to the individual publisher as copyright holder. 


\title{
SPATIAL SCALING OF PREVALENCE AND POPULATION VARIATION IN THREE GRASSLAND SPARROWS
}

\author{
L. Lynnette Dornak ${ }^{1,2,3}$, Narayani Barve ${ }^{2}$, And A. Townsend Peterson ${ }^{2}$ \\ ${ }^{1}$ Department of Geography, 213 Lindley Hall, University of Kansas, 1475 Jayhawk Blvd Lawrence, KS 66045-7575 \\ ${ }^{2}$ Biodiversity Institute, University of Kansas, 1475 Jayhawk Blvd Lawrence, KS 66045-7575
}

\begin{abstract}
Henslow's Sparrows (Ammodramus henslowii) are distributed in tallgrass prairies in central North America; however, this species is restricted further to specific habitats within these prairies-large expanses with relatively little woody vegetation but an accumulation of standing grasses and forbs, conditions that result from infrequent disturbances by fire, mowing, or grazing. Henslow's Sparrows have been documented to be unpredictable at breeding sites from year to year, but studies to date have considered only local spatial scales. We compared resettlement behavior (prevalence of occurrence and variation in abundance) of Henslow's Sparrows to that of two other grassland sparrows, Grasshopper Sparrows (A. savannarum) and Savannah Sparrows (Passerculus sandwichensis), across multiple spatial resolutions. In Henslow's Sparrows, prevalence was lower and variation in abundance was greater than in the other two species. Indeed, Henslow's Sparrows do not occur consistently at extents of less than $120000 \mathrm{~km}^{2}$, suggesting nomadic characteristics of where they breed from year to year. We suggest that these patterns reflect Henslow's Sparrows' responses to frequently changing habitat, such that this species is tracking spatiotemporal changes in optimal habitat that result from disturbances broadly across regional landscapes.
\end{abstract}

Key words: Grasshopper Sparrow, Henslow's Sparrow, population, prevalence, Savannah Sparrow, nomadism, variation.

\section{Escalamiento Espacial de la Prevalencia y de la Variación Poblacional en Tres Gorriones de Pastizal}

\begin{abstract}
Resumen. Ammodramus henslowii habita en las praderas de pastos altos en el centro de América del Norte; sin embargo, a lo largo de estas praderas, esta especie se restringe a algunos hábitats específicos-generalmente grandes extensiones con relativamente poca vegetación leñosa; la acumulación de pastos permanentes y otras hierbas resultado de trastornos poco frecuentes (fuego, siega o pastoreo). A. henslowii ha mostrado ser poco predecible en cuanto a los sitios de reproducción de un año a otro; sin embargo, a la fecha, los estudios sólo han considerado escalas espaciales locales. En este estudio, comparamos el comportamiento de reasentamiento (predominio de ocurrencia y variación en la abundancia) de $A$. henslowii con otras dos especies de gorriones de pastizales, A. savannarum y Passerculus sandwichensis, a través de múltiples resoluciones espaciales. A. henslowii mostró un predominio más bajo y una mayor variación en la abundancia que las otras dos especies. De hecho, $A$. henslowii no se encuentra frecuentemente en extensiones menores a $120000 \mathrm{~km}^{2}$, lo que sugiere características nómades en cuanto a los lugares de reproducción de un año a otro. Sugerimos que estos patrones reflejan la respuesta de $A$. henslowii a los frecuentes cambios en el hábitat, de tal manera que esta especie está siguiendo cambios espaciotemporales en el hábitat óptimo debido a las alteraciones en los paisajes regionales.
\end{abstract}

\section{INTRODUCTION}

Henslow's Sparrows (Ammodramus henslowii) breed in remnants of tallgrass prairie and similar grassland habitats scattered across the Midwest and portions of northeastern North America (Pruitt 1996, Herkert et al. 2002). This species, once common (Robbins et al. 2002), is now recorded only infrequently on North American Breeding Bird Survey (BBS) routes across much of its original breeding range
(Sauer et al. 2011). Its breeding habitat, formerly relatively contiguous in prairies and coastal marshes from the northeastern seaboard to the western limit of tallgrass prairie (Hyde 1939, Pruitt 1996), is now patchy, with few documented core areas. Henslow's Sparrows are not only uncommon, they are also unpredictable in grasslands that appear suitable (Hyde 1939, Wiens 1969, Skipper 1998). For example, for reasons unclear, this species may be present one year but not return to the area in subsequent years, even though the vegetation

Manuscript received 22 March 2012; accepted 4 August 2012.

${ }^{3}$ E-mail: picoides@ku.edu

The Condor, Vol. 115, Number 1, pages 186-197. ISSN 0010-5422, electronic ISSN 1938-5422. @ 2013 by The Cooper Ornithological Society. All rights reserved. Please direct all requests for permission to photocopy or reproduce article content through the University of California Press's Rights and Permissions website, http://www.ucpressjournals.com/ reprintInfo.asp. DOI: 10.1525/cond.2013.120055 
appears unchanged. Dornak (2010) found that on BBS routes, Henslow's Sparrow breeding sites were less predictable from year to year than those of the Grasshopper (A. savannarum) and Savannah (Passerculus sandwichensis) sparrows. That study concluded that Henslow's Sparrows were possibly nomadic because birds were not consistently resettling at the same sites for breeding.

Nomadism is the irregular or undirected dispersal of individuals following patchy and unpredictably available resources across a landscape (Sinclair 1984, Dean 1997). It is in effect temporal turnover of populations (Allen and Saunders 2002). Nomadism can occur among individuals, groups of individuals, or entire populations (Andersson 1980), and across multiple spatial scales (Dean 1997). It is most commonly observed in species that live in highly variable environments, such as the North American grasslands (Bragg 1995), where the ability to track resources (e.g., food or suitable nesting sites) and colonize new breeding areas quickly in response to changing environmental conditions is advantageous (Cody 1985, Igl and Johnson 1999)

Dornak (2010) analyzed nomadism only at one spatial scale, so it remains unclear if these grassland sparrows are nomadic over multiple scales and (most importantly) at what scales the differences in prevalence between them are manifested. In this study we investigate these questions by comparing the occurrence and variation in abundance patterns of Henslow's, Grasshopper, and Savannah sparrows at spatial resolutions spanning six orders of magnitude $\left(0.5-511360 \mathrm{~km}^{2}\right)$. We chose these three species for comparison because they nest primarily in grassland (Vickery et al. 1999), their tolerances of grassland succession differ (Wheelwright and Rising 1993, Vickery 1996, Powell 2006), and their levels of fidelity to nest sites differ (Bédard and LaPoint 1984, Skipper 1998, Jones et al. 2007). Although these species differ with respect to microhabitat preferences, here we focus on each species' predictability of occurrence within its respective microhabitat.

\section{METHODS}

\section{STUDY AREA}

Our analysis was restricted to the overall known extent of Henslow's Sparrows' breeding occurrence as recorded by the BBS (Fig. 1), which subsumes the site-to-site variation that is the subject of this paper. Although Grasshopper and Savannah sparrows have wider breeding distributions, restricting the area analyzed to the distribution of Henslow's Sparrows reduces variation resulting from irrelevant processes manifested beyond the range of the focal species (Dornak 2010). The reduced area covers $2.1 \times$ $10^{6} \mathrm{~km}^{2}$ and is dominated by agriculture, both pasture and croplands, interspersed with patches of woodlands, shrub, wetlands, urban and developed areas, fallow pastures, and native prairie.

\section{OCCURRENCE DATA}

We extracted occurrence data from the BBS database (Sauer et al. 2011). The BBS is conducted annually along $>4000$ roadside census routes across the U.S., southern Canada, and northern Mexico, and it is the only broad-scale, standardized, long-term system that monitors trends of breeding bird in North America (Sauer et al. 2011). Each $39.5-\mathrm{km}$ route has 50 stops (observation points) distributed every $0.8 \mathrm{~km}$. Each year at a time appropriate for the region ( June in the range of Henslow's Sparrow), observers record all birds seen or heard at each stop for $3 \mathrm{~min}$ (Sauer et al. 2011). We used 50 BBS routes per species, representing almost all routes (see below) on which Henslow's Sparrows have been detected and paralleling past analyses (Dornak 2010). Although the system is not without inherent bias, the BBS is the only standardized database for rangewide studies of North American birds, so BBS data are most appropriate as the basis for our analyses. To control for biases in observer consistency (Dornak 2010), we used only data from BBS routes run by a single observer across the study period, which reduced the sample size of routes on which Henslow's Sparrow has been detected to 50. We used two metrics to describe the species' yearly resettlement patterns: prevalence of occurrence and coefficient of variation in abundance (Dornak 2010). Prevalence of occurrence describes the consistency of resettlement of an area by the species over multiple years. We calculated it by dividing the total number of years that a species was observed on a route by the total years that the route was surveyed. The coefficient of variation of numbers of individuals of the species detected is a standardized metric of variation, calculated as standard deviation divided by the mean abundance.

\section{SPATIAL RESOLUTION GRADIENT}

All analyses are based on regroupings of records of the three species within and among stops on BBS routes for development of a multiple-scale approach crossing orders of magnitude. We analyzed data (1) below the spatial scale of a BBS route by creating subgroups of BBS stops, (2) at the route level, and (3) above the route level by combining routes within regions (Fig. 2). That is, within each BBS route in the sample, the finest resolution was represented by the individual stop (each representing sampling of $\sim 0.5 \mathrm{~km}^{2}$ ), which we grouped into 25 pairs of consecutive stops $\left(\sim 1.1 \mathrm{~km}^{2}\right.$ per pair). For successively broader spatial scales, we aggregated stops into 10 groups of 5 stops ( $\sim 3.1 \mathrm{~km}^{2}$ per group), 5 groups of 10 stops ( $\sim 6.3 \mathrm{~km}^{2}$ per group), 2 groups of 25 stops $\left(\sim 15.9 \mathrm{~km}^{2}\right.$ per group), and finally the full BBS route $\left(\sim 32 \mathrm{~km}^{2} ;\right.$ Fig. 2).

We developed coarser resolutions by dividing Henslow's Sparrow's range into quadrants of equal area, in three steps, yielding 4 regions of $510000 \mathrm{~km}^{2}, 16$ of $126000 \mathrm{~km}^{2}$, and 64 of $31000 \mathrm{~km}^{2}$ (Fig. 2). We analyzed all three species' occurrences across this same suite of areas. In this way, prevalence and variability could be visualized across a spectrum of 

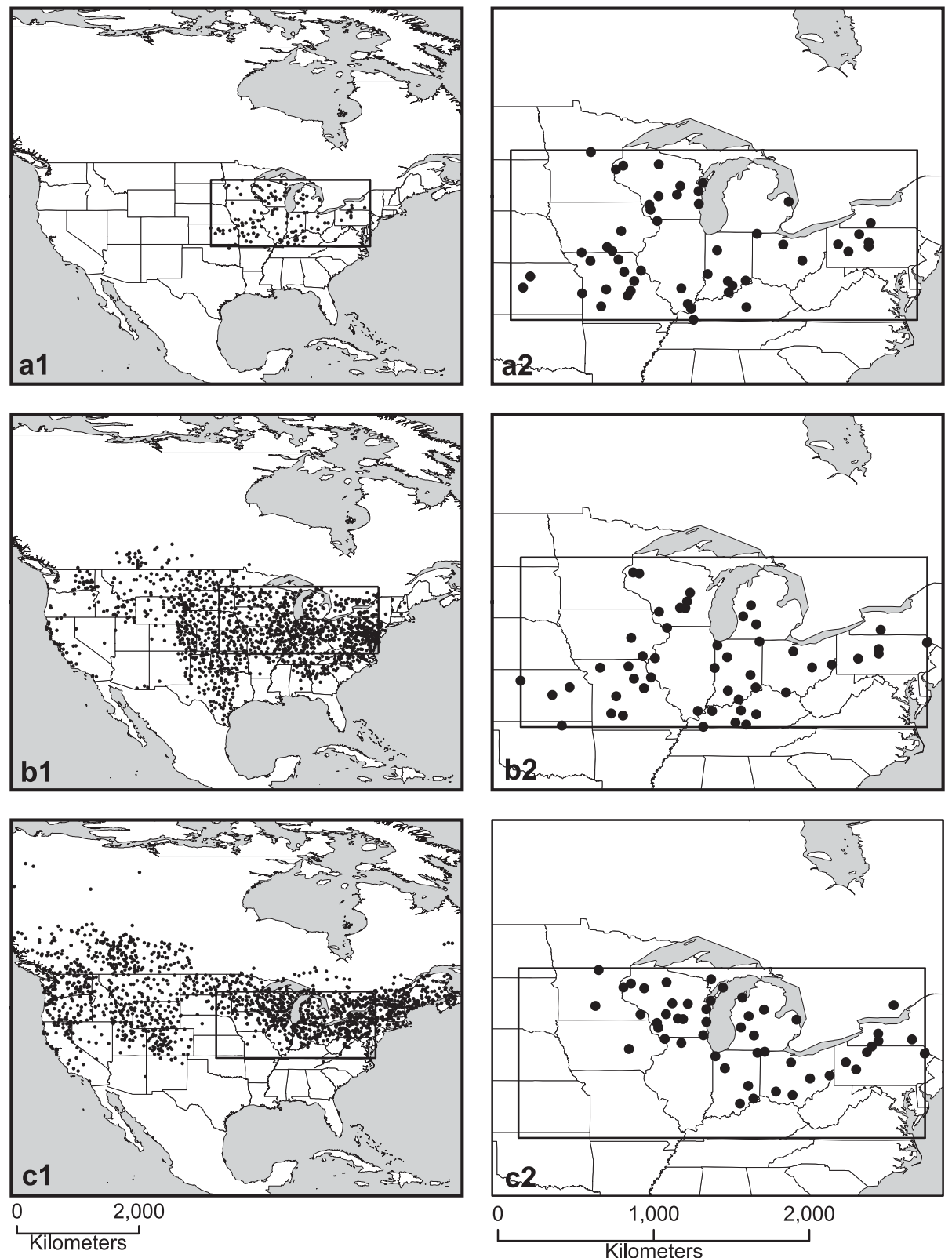

FIGURE 1. Breeding Bird Survey routes reporting the Henslow's (a1), Grasshopper (b1), and Savannah (c1) sparrows (1) and the subset $(\mathrm{a} 2, \mathrm{~b} 2, \mathrm{c} 2)$ used in our analyses, restricted to routes within the Henslow's Sparrow's breeding range and with a single observer.

spatial resolutions and extents ranging from $0.5 \mathrm{~km}^{2}$ to $0.5 \times$ $10^{6} \mathrm{~km}^{2}$, or 6 orders of magnitude of area. The route-based areas and the quadrant-based areas are not completely compatible and consistent with one another, as the smaller quadrants varied in number of routes and thoroughness of sampling. For this reason, we based one confirmatory rarefaction test only on extents at and below that of entire routes (see below).

\section{STATISTICAL ANALYSIS}

First, we tested all levels for normality and homogeneity of variances. Because most samples were either not normally distributed or their variances were not homogeneous, we used nonparametric analyses throughout. Kruskal-Wallis ranksum tests to assess differences between species at various resolutions within the original data sets (i.e., not the rarefied data sets, see below); when differences were significant, we used post hoc Mann-Whitney $U$-tests to differentiate between groups of species. We considered results of Kruskal-Wallis significant at $\alpha=0.05$. To control for type I errors with multiple significance tests, we applied Bonferroni corrections to all Mann-Whitney $U$-tests so report their results as significant at $\alpha=0.0167$. Statistical analyses were performed with SPSS, 


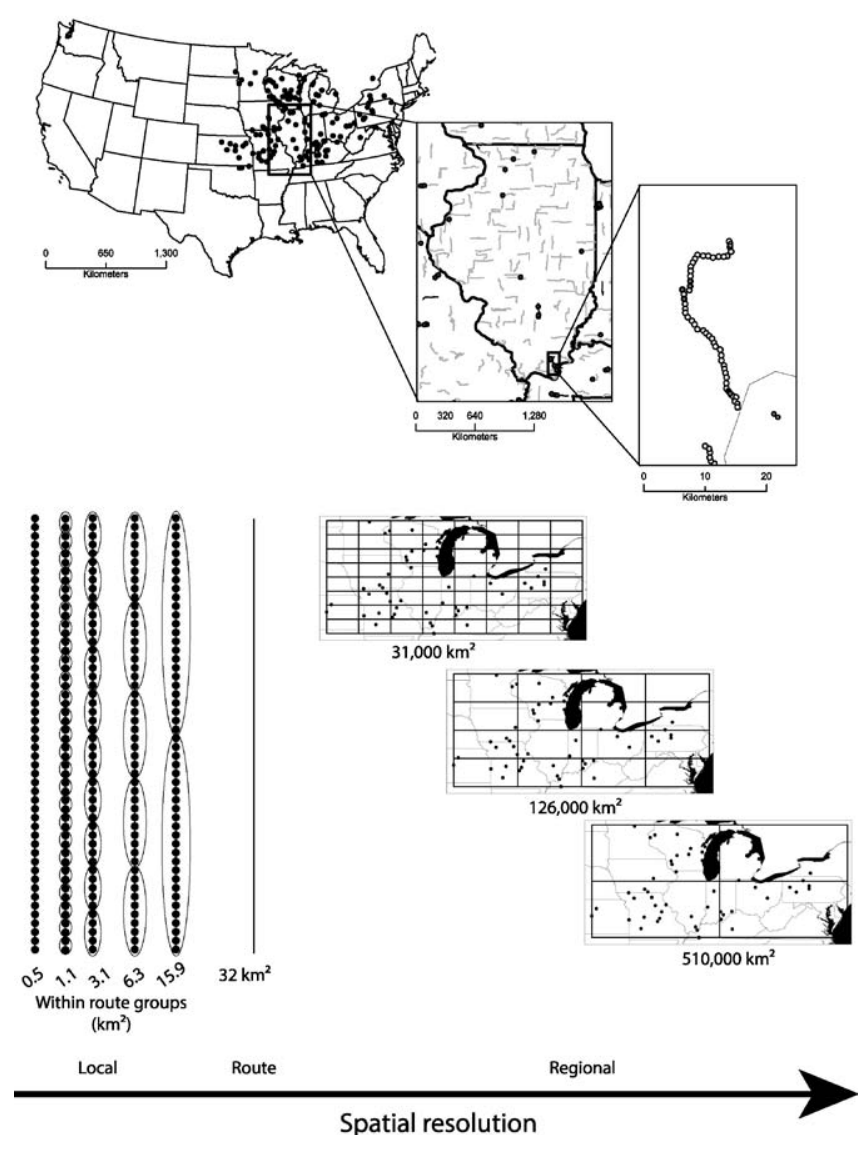

FIGURE 2. Top: Breeding Bird Survey (BBS) routes (points) where Henslow's Sparrows were detected 2000-2007. First inset shows all BBS routes where Henslow's Sparrows were detected (black lines) in Illinois. Second inset shows specific BBS stops where Henslow's Sparrows were recorded on one example route. Bottom: illustration of groups of stops and routes used in comparisons across spatial resolutions.

version 17.0 (SPSS 2008) and with R (R Development Core Team 2011). However, because successive resolutions are not independent of one another, creating potential for bias, testing was explored in further depth, as follows.

Prevalence values were plotted across the spectrum of spatial resolutions as curves connecting $(0,0)$ (no area, no presence) and (510 $\left.000 \mathrm{~km}^{2}, 1\right)$ (full range, constant presence). As a hypothetical example, these curves would be highly convex in a species such as the American Robin (Turdus migratorius) with a pattern of very consistent local occurrence but concave in highly nomadic species with consistent occurrence only at broad extents (Fig. 3). To compare these curves in terms of their concave versus convex nature, and bearing in mind that the same data that make up the data for one spatial resolution contribute data at the next coarser resolution, making different resolutions non-independent, we calculated the area under each

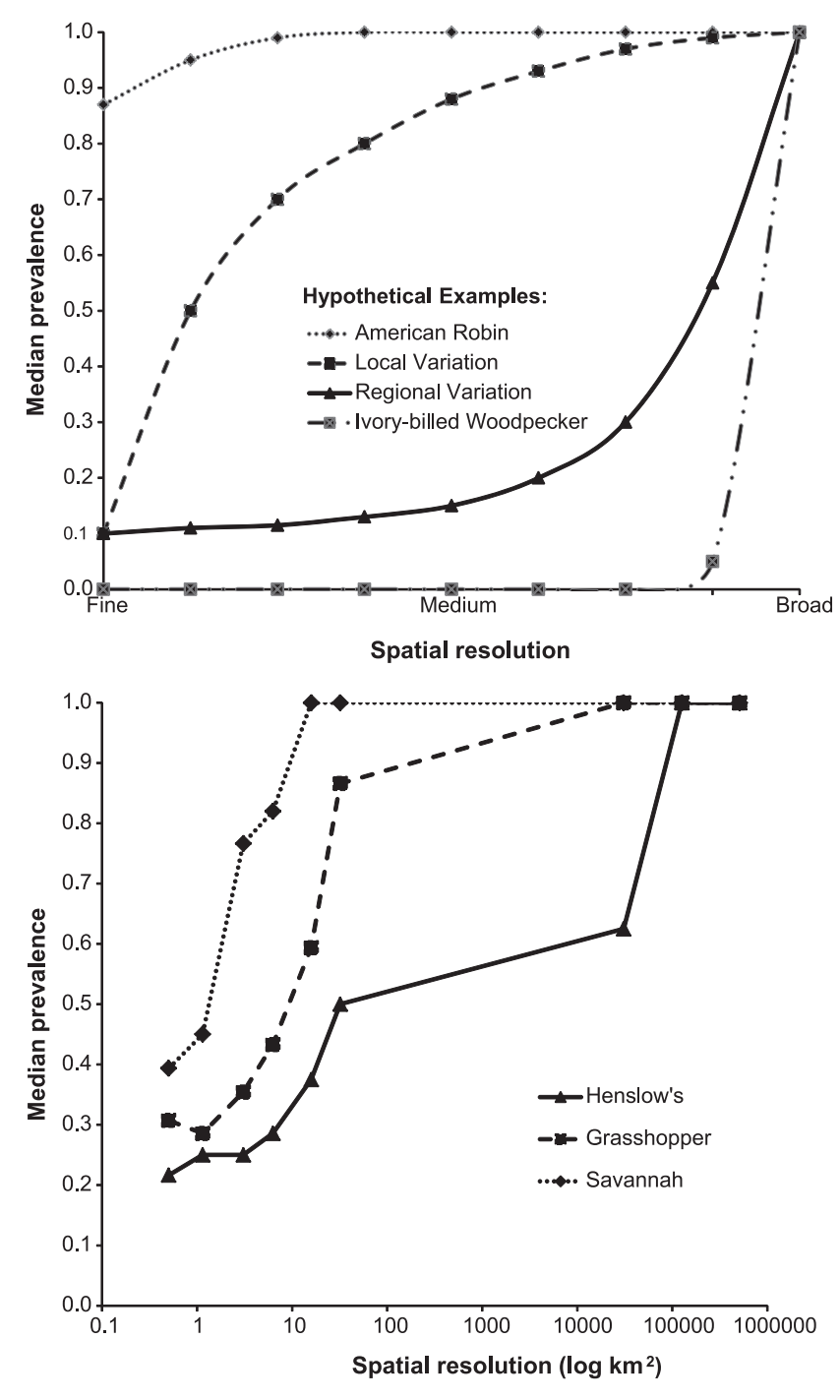

FIGURE 3. Patterns of prevalence across spatial scales. Top: hypothetical examples, illustrating the range of variation from the American Robin (Turdus migratorius) (ubiquitous and constantly present at most sites) to the fabled Ivory-billed Woodpecker (Campephilus principalis), which never seems to be in any particular place. Bottom: patterns observed in the three species of grassland sparrows.

species' curve as a means of building comparisons across spatial scales. To permit statistical comparisons of these areas, we used a $50 \%$ bootstrap subsampling of the data from which the curves are estimated (i.e., the stop-level BBS data) to generate 1000 replicates from which we generated distributions of areas reflecting the intrinsic variability in the data. To avoid violating assumptions of independence, we used area-under-the-curve analysis to consider all resolutions concurrently. We also applied this method to coefficients of variation of abundance values to compare differences among the species. For these calculations we used programs developed by N. Barve that are available upon request from the authors. 


\section{TESTS FOR BIASES}

Henslow's Sparrows are observed less often per BBS stop and are more difficult to detect than either Grasshopper or Savannah sparrows (Dornak 2010). Henslow's Sparrows also appear to be less abundant than the other two species analyzed herein. We argue that the effects of the differences in detection and abundance are similar, such that, within our analyses, a species with low detectability will present a pattern of occurrence similar to that of one with low abundance. We conducted tests to verify that the low prevalence of Henslow's Sparrows is not simply a consequence of lower numbers of individuals or lower detectability of similar numbers of individuals. To this end, we treated detection and abundance as a single phenomenon and subsampled occurrences of Grasshopper and Savannah sparrows at the stop level across the study period to produce a data set that matched abundances overall to the Henslow's Sparrow BBS data. Because we resampled randomly from Grasshopper and Savannah sparrow occurrence data to equal Henslow's Sparrow abundances, we effectively manipulated overall numbers without changing the spatial structure; then, we tested whether that spatial structure differed by species. We reassembled rarefied data sets into sets of presence-absence data and analyzed them as described above. Because of the random nature of the resampling method, abundances at some stops were reduced, but abundances were eliminated entirely at other stops. We randomized and repeated the resampling to generate 200 rarefied data sets each for Grasshopper and Savannah sparrows. We believe that our methods of reducing the abundances of Grasshopper and Savannah sparrows also reduced the effects of detection differences among the species, such that prevalence patterns in our results reflect natural phenomena and not density biases. We restricted these analyses to area under the curve and did not repeat the Kruskal-Wallis and Mann-Whitney $U$-test comparisons.

We constructed spatial resolutions and associated prevalence values from the rarefied data as described above and calculated median prevalence for each resolution; however, owing to inconsistencies between the route-based and quadrant-based data, we did these analyses only for resolutions at and below the route level. We calculated areas under the curve for each rarefied subset, applying the same parameters used with the original data sets. To consider intrinsic variability in the data underlying each curve for each of these 200 rarefied data sets per species, we again used 50\% bootstrap subsampling to generate 1000 randomized values. We averaged these 1000 bootstrap values and created a histogram of the distribution of each of the 200 rarefied data sets. We compared the observed area for Henslow's Sparrows to those of the bootstrapped distributions. Because the data in the coarser (regional) resolutions mask patterns that emerge at finer resolutions, and in light of the inconsistencies of resolutions noted above for levels above the route, we limited this analysis to resolutions of $0.5 \mathrm{~km}^{2}$ (stop) through $32 \mathrm{~km}^{2}$ (route).

\section{RESULTS}

\section{PREVALENCE OF OCCURRENCE}

At most spatial resolutions, prevalence was lowest for Henslow's Sparrows and higher for the other two species. Differences between species were significant at all spatial resolutions $(P<$ 0.001 ) except $125000 \mathrm{~km}^{2}(P=0.185)$ and $510000 \mathrm{~km}^{2}$ (Table 1). Analysis for the latter resolution did not merit further consideration because all species had a median prevalence of 1.0, so no differences could be detected. At all resolutions at or below $31000 \mathrm{~km}^{2}$, however, the prevalence of Henslow's Sparrows was significantly lower than that of Savannah and Grasshopper sparrows $(P<0.01$, Table 1$)$. The consistency with which Henslow's Sparrows returned to sites at these extents varied: $22 \%\left(0.5 \mathrm{~km}^{2}\right), 50 \%\left(32 \mathrm{~km}^{2}\right)$, and $63 \%\left(31000 \mathrm{~km}^{2}\right)$; the species was not consistently present (i.e., prevalence $>75 \%$ ) at sites until the resolution was broadened to cover $126000 \mathrm{~km}^{2}$. Grasshopper and Savannah sparrows were consistently prevalent at much finer resolutions, the $32-\mathrm{km}^{2}(87 \%)$ and $3.1-\mathrm{km}^{2}$ $(77 \%)$ resolutions, respectively (Fig. 3). The prevalence of Grasshopper Sparrows was significantly lower than that of Savannah Sparrows at all resolutions through $32 \mathrm{~km}^{2}$ (Table 1, Fig. 3). However, as mentioned above, these comparisons are complicated because prevalences at different spatial resolutions are not independent of one another.

The comparisons of prevalence curves offer a means of comparing the species without the complication of non-independence of successive spatial resolutions. In all, the curves differed significantly $(P<0.001)$. The Henslow's Sparrow curve was significantly lower than those curves of Grasshopper $(z=$ -38.72; $P<0.001)$ and Savannah $(z=-38.72 ; P<0.001)$ sparrows; similarly, the Grasshopper Sparrow curve was lower than that of Savannah Sparrows $(z=-21.95 ; P<0.001)$.

Finally, we used rarefaction analyses to check that the differences in prevalence described above were not an artifact of overall lower abundance and/or detectability. We found that, at least at finer spatial resolutions, Henslow's Sparrow prevalences were still significantly $(P<0.005)$ less consistent than either of the other two species, even when the abundances of the other two species were rarefied (Fig. 4). As a result, we conclude that the less consistent occurrence of Henslow's Sparrows is indeed a reality, and not an artifact.

\section{VARIATION IN ABUNDANCE}

Significant differences among species in tests for variation in abundance were found at only two resolutions, $32 \mathrm{~km}^{2}(P$ $=0.049)$ and $126000 \mathrm{~km}^{2}(P=0.005$; Table 1$)$. At $32 \mathrm{~km}^{2}$, the ranked variability in abundance of Grasshopper Sparrows (median $=0.43$ ) was higher than that of Savannah Sparrows $(0.32, P=0.010)$. At $126000 \mathrm{~km}^{2}$, the ranked variability of 
TABLE 1. Comparisons of Henslow's, Grasshopper, and Savannah sparrows across multiple spatial resolutions on the basis of Breeding Bird Survey data from 2000 to 2007.

\begin{tabular}{|c|c|c|c|c|c|c|c|c|c|}
\hline & \multicolumn{9}{|c|}{ Spatial resolution $\left(\mathrm{km}^{2}\right)$} \\
\hline & 0.5 & 1.1 & 3.1 & 6.3 & 15.9 & 32 & 31000 & 126000 & 510000 \\
\hline \multicolumn{10}{|c|}{ Kruskal-Wallis rank-sum tests } \\
\hline \multicolumn{10}{|c|}{ Prevalence } \\
\hline$H$ & 32.97 & 39.73 & 87.95 & 44.50 & 45.72 & 53.23 & 19.76 & 3.37 & - \\
\hline df & 2 & 2 & 2 & 2 & 2 & 2 & 2 & 2 & - \\
\hline$P$ & $<0.001^{\mathrm{a}}$ & $<0.001^{\mathrm{a}}$ & $<0.001^{\mathrm{a}}$ & $<0.001^{\mathrm{a}}$ & $<0.001^{\mathrm{a}}$ & $<0.001^{\mathrm{a}}$ & $<0.001^{\mathrm{a}}$ & 0.185 & - \\
\hline \multicolumn{10}{|c|}{ Coefficient of variation } \\
\hline$H$ & 5.37 & 3.82 & 2.43 & 3.99 & 3.55 & 6.03 & 5.31 & 10.56 & 5.05 \\
\hline $\mathrm{df}$ & 2 & 2 & 2 & 2 & 2 & 2 & 2 & 2 & 2 \\
\hline$P$ & 0.068 & 0.148 & 0.297 & 0.136 & 0.169 & $0.049^{\mathrm{a}}$ & 0.07 & $0.005^{\mathrm{a}}$ & 0.08 \\
\hline \multicolumn{10}{|c|}{ Mann-Whitney $U$-tests } \\
\hline \multicolumn{10}{|c|}{ Prevalence } \\
\hline \multicolumn{10}{|c|}{ Henslow's-Grasshopper } \\
\hline$U$ & 783.0 & 858.5 & 713.0 & 762.0 & 726.0 & 648.5 & 220.5 & - & \\
\hline$z$ & -3.23 & -2.71 & -3.71 & -3.37 & -3.63 & -4.19 & -2.72 & - & \\
\hline$P$ & $0.001^{\mathrm{b}}$ & $0.007^{\mathrm{b}}$ & $<0.001^{\mathrm{b}}$ & $0.001^{\mathrm{b}}$ & $<0.001^{\mathrm{b}}$ & $<0.001^{\mathrm{b}}$ & $0.006^{\mathrm{b}}$ & - & \\
\hline \multicolumn{10}{|c|}{ Henslow's-Savannah } \\
\hline$U$ & 428.5 & 328.5 & 42.0 & 302.0 & 286.0 & 268.0 & 136.5 & - & \\
\hline$z$ & -5.67 & -6.37 & -8.34 & -6.54 & -6.71 & -7.05 & -4.22 & - & \\
\hline$P$ & $<0.001^{\mathrm{b}}$ & $<0.001^{\mathrm{b}}$ & $<0.001^{\mathrm{b}}$ & $<0.001^{\mathrm{b}}$ & $<0.001^{\mathrm{b}}$ & $<0.001^{\mathrm{b}}$ & $<0.001^{\mathrm{b}}$ & - & \\
\hline \multicolumn{10}{|c|}{ Savannah-Grasshopper } \\
\hline$U$ & 872.5 & 755.5 & 222.0 & 739.0 & 800.0 & 771.0 & 253.0 & - & \\
\hline$z$ & -2.60 & -3.41 & -7.09 & -3.53 & -3.22 & -3.68 & -2.07 & - & \\
\hline$P$ & $0.009^{\mathrm{b}}$ & $0.001^{\mathrm{b}}$ & $<0.001^{\mathrm{b}}$ & $<0.001^{\mathrm{b}}$ & $0.001^{\mathrm{b}}$ & $<0.001^{\mathrm{b}}$ & 0.039 & - & \\
\hline \multicolumn{10}{|c|}{ Coefficient of variation } \\
\hline \multicolumn{10}{|c|}{ Henslow's-Grasshopper } \\
\hline$U$ & - & - & - & - & - & 1149.5 & - & 57.0 & - \\
\hline$z$ & - & - & - & - & - & -0.70 & - & -0.84 & - \\
\hline$P$ & - & - & - & - & - & 0.487 & - & 0.401 & - \\
\hline \multicolumn{10}{|c|}{ Henslow's-Savannah } \\
\hline$U$ & - & - & - & - & - & 1049.0 & - & 15.5 & - \\
\hline$z$ & - & - & - & - & - & -1.39 & - & -3.07 & - \\
\hline$P$ & - & - & - & - & - & 0.165 & - & $0.002^{\mathrm{b}}$ & - \\
\hline \multicolumn{10}{|c|}{ Savannah-Grasshopper } \\
\hline$U$ & - & - & - & - & - & 875.0 & - & 21.0 & - \\
\hline$z$ & - & - & - & - & - & -2.59 & - & -2.39 & - \\
\hline$P$ & - & - & - & - & - & $0.01^{\mathrm{b}}$ & - & $0.017^{\mathrm{b}}$ & - \\
\hline
\end{tabular}

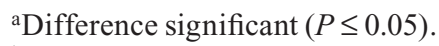

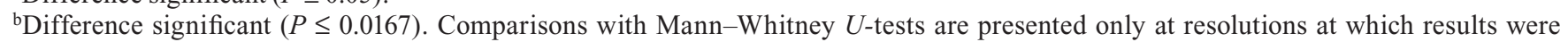
significant by the Kruskal-Wallis test.

Henslow's Sparrows (0.53) was higher than that of Savannah Sparrows (0.23, $P=0.002$; Table 1). At $126000 \mathrm{~km}^{2}$, variation in Grasshopper Sparrows (0.41) was almost significantly larger than that of Savannah Sparrows $(P=0.017$; Table 1).

Comparisons of areas under curves revealed significant differences between species $(P<0.001)$. The Henslow's Sparrow curve was significantly higher than that of both Grasshopper $(z=$ $-25.79 ; P<0.001)$ and Savannah $(z=-38.72 ; P<0.001)$ sparrows; hence, Henslow's Sparrow abundance was more variable than that of the other grassland sparrows. The curve for Grasshopper
Sparrows was significantly higher than that for Savannah Sparrows $(z=-38.72 ; P<0.001 ;$ Fig. 5$)$. We did not conduct rarefaction manipulations for population variation because of confusion over how best to manipulate individual occurrences in this case.

\section{DISCUSSION}

\section{COMPARISONS OF SPECIES}

Across their geographic distribution, Henslow's Sparrows do not use breeding areas consistently from year to year; as a 

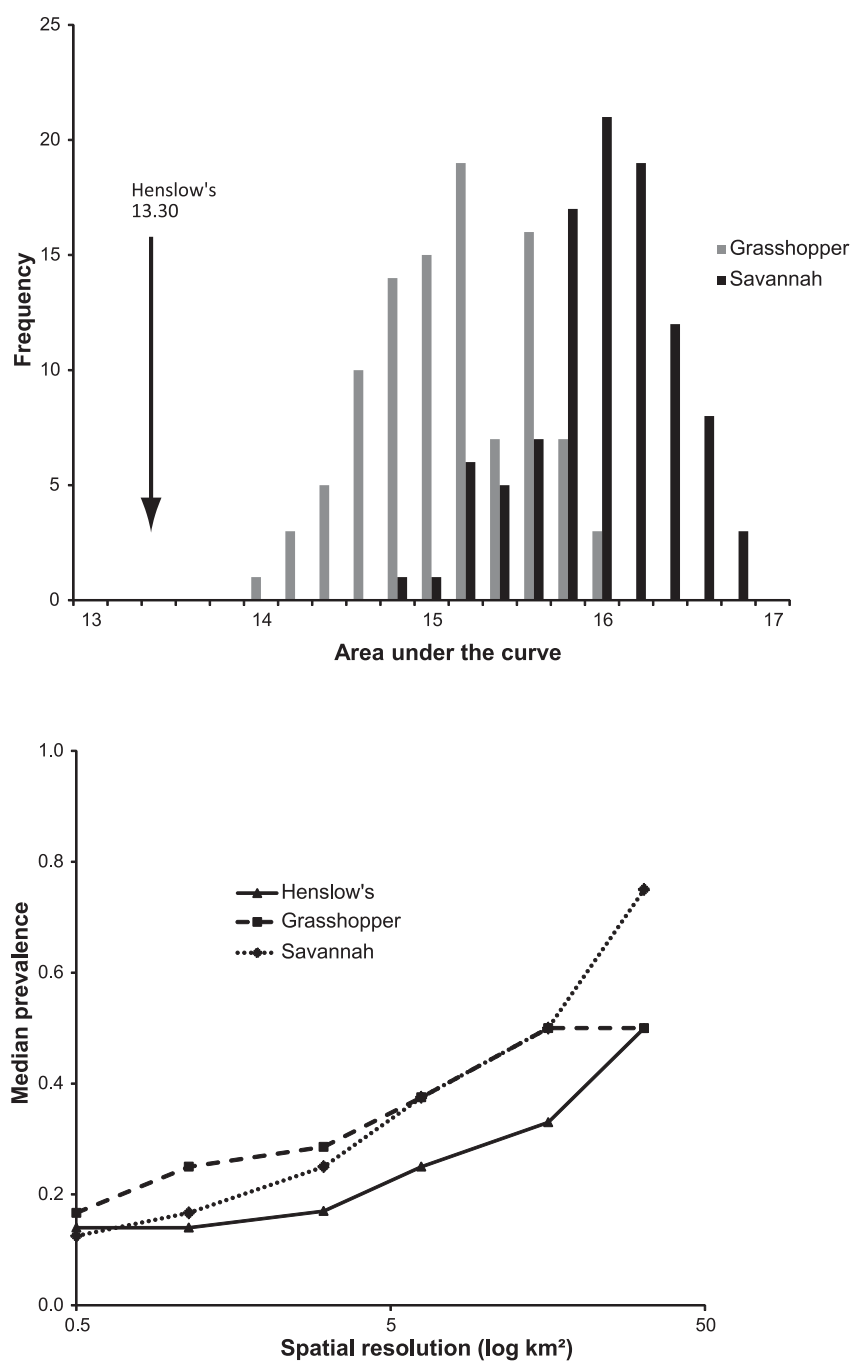

FIGURE 4. Top: frequency of mean bootstrapped values of area under the prevalence curve across 6 spatial resolutions $\left(0.5-32 \mathrm{~km}^{2}\right)$ for rarefied population data for the Grasshopper and Savannah sparrows and the observed value for Henslow's Sparrow. Bottom: median prevalence by spatial resolution of rarefied abundance data for the three species.

consequence, their prevalence of occurrence was significantly lower than that of Grasshopper and Savannah sparrows at most spatial resolutions analyzed. At local scales $\left(0.5 \mathrm{~km}^{2}\right)$, prevalences were low for all three species; however, as spatial resolution coarsened, prevalences of Grasshopper and Savannah sparrows increased, but that of Henslow's Sparrows remained low. Indeed, Henslow's Sparrows returned to entire BBS routes $\left(30 \mathrm{~km}^{2}\right)$ in only $50 \%$ of years sampled and were at times conspicuously absent even from broader regions ( $31000 \mathrm{~km}^{2}$ at $63 \%$ prevalence). Statistical comparisons at individual resolutions, though informative, violate assumptions of independence between tests; therefore, the area under the curve may better characterize the prevalence of occurrence of the three species across multiple

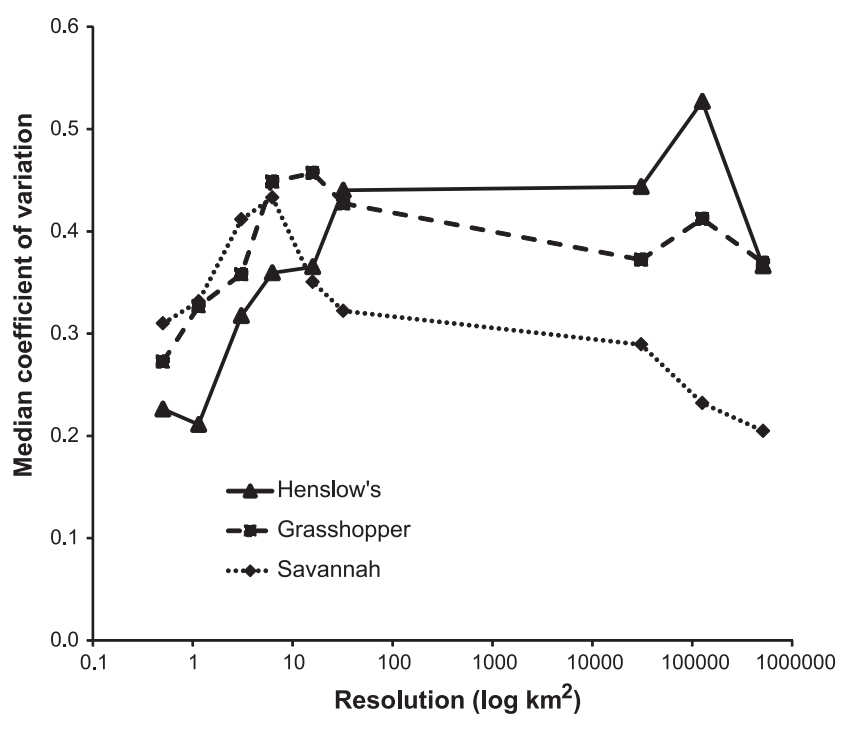

FIGURE 5. Patterns of coefficient of variation across spatial scales in Henslow's, Grasshopper, and Savannah sparrows.

spatial resolutions. The prevalence curve of Henslow's Sparrows was more concave - the area beneath the curve was less - than the curves of Savannah and Grasshopper sparrows, supporting the idea that Henslow's Sparrows are indeed less prevalent than the other grassland sparrows. These results were confirmed even after adjustment for the three species' differences in detectability or abundance.

No clear pattern emerged from tests of differences in variation between species at individual spatial resolutions; at only two spatial resolutions were differences between species significant. The area under the curve proved to be more useful, showing that Henslow's Sparrows were more variable overall (highest curve) than either Grasshopper or Savannah sparrows, the latter species having the lowest variation (lowest curve). Henslow's Sparrows thus showed the most variation in year-to-year abundance, and of the three species its prevalence was lowest. Savannah Sparrows, conversely, showed the smallest variation in abundance and the highest prevalence of occurrence.

Results from this study corroborate patterns of occurrence suspected by previous researchers (Hyde 1939, Wiens 1969, Skipper 1998) and documented in a preliminary manner by Dornak (2010). Not only are Henslow's Sparrows less prevalent and more variable than the other two sparrow species, but they are not predictably present until extents of $120000 \mathrm{~km}^{2}$ are considered; these contrasts among species are not simple consequences of lower abundance or detectability. So, then, why is Henslow's Sparrow's prevalence lower than that of Grasshopper and Savannah sparrows across multiple spatial resolutions, when, in our study area, all three species are obligate grassland nesters? These observations might indicate that too much habitat exists for too few 
individuals to fill (Cody 1985) or some unusual life-history strategy adapted to life in a spatially and temporally dynamic landscape.

Our results support strongly the hypothesis that Henslow's Sparrows are nomadic in successive breeding seasons across multiple spatial resolutions. Nomadism is a special form of dispersal that is characterized by irregular movements of individuals, groups of individuals, or whole populations to different areas from year to year or within a season (Sinclair 1984, Dean 1997). Nomadism develops most commonly when limiting resources fluctuate spatiotemporally and become patchy and unpredictably available across a region (Sinclair 1984, Dean 1997).

Nomadism has a variety of predictors that appear to be linked to spatial scales. At fine scales, factors such as age, mate loss (Newton and Marquis 1982), unsuccessful attempts to breed in a previous year (Harvey et al. 1979, Greenwood and Harvey 1982, Newton and Marquis 1982), and conspecific attraction (Stamps 1987, 1988, Ahlering et al. 2006) can influence whether an individual or group of individuals returns to the area in which it previously bred. At broader scales, factors such as regional weather patterns (Wiens 1986, Johnson and Grier 1988, Kantrud and Faanes 1979), precipitation in arid landscapes (Davies 1984, Dorfman and Kingsford 2001), and land use (Milton et al. 1994) affect resource distributions and may affect population variation and a species' regional distribution. Some factors have cross-scale influences; food resources, for example, can cause fine-scale movements of birds tracking insects' emergence (Dean 1997) or broad-scale variability in species following abundant seed masts (Andersson 1980, Sinclair 1984, Dean 1997) or high densities of microtine rodents (Martin 1989, Korpimäki and Norrdahl 1991).

We suspect that Henslow's Sparrows may be responding to multiple factors causing nomadic movements across spatial scales (Allen and Saunders 2006). At finer resolutions, patchto-patch movements may be the result of conspecific attraction and patch-level land uses. Henslow's Sparrows are loosely colonial (Hyde 1939, Wiens 1969) and may require an aggregation of conspecifics to settle an area, or use presence of conspecifics to make decisions about the suitability of a patch (Stamps 1987, 1988, Ahlering et al. 2006). Patch-level disturbance may also result in year-to-year variation in settlement: Henslow's Sparrow habitat occurs primarily on managed lands (Herkert et al. 1996) where burning, grazing, and haying are common disturbances and may alter the habitat's suitability between management units. Recently (i.e., around 1 year) disturbed areas are not optimal for Henslow's Sparrows (Powell 2006), although some males may use such areas (Swengel 1996, Herkert and Glass 1999). As time since disturbance accumulates, plant biomass (standing live, dead, and thatch) increases, and the habitat becomes more attractive. Over succeeding years, more males establish territories, increasing abundance on the patch and conspecific attraction. When the habitat is disturbed once again, however, habitat suitability is reduced and the cycle is repeated. Therefore, in species that select habitats regulated by short disturbance cycles, prevalence of occurrence should be lower and annual variation in abundance should be higher, particularly when the spatial grain of the disturbance regime is large (Robbins et al. 2002). Henslow's Sparrows are known not to return to sites where they previously nested although the sites appear unchanged. We propose that conspecific attraction may influence their settlement before individuals return sites used the previous year (i.e., opportunistic settling; Johnson and Grier 1988).

At broader spatial scales, weather patterns and regional variation in land use may also contribute to the prevalence patterns we identified across spatial resolutions. In the interior of the U.S., year-to-year variation in precipitation and temperature is great (Bragg 1995). Grasslands respond to extreme or unseasonable weather (e.g., drought or late springs) rather quickly (Wiens 1986), and this response can influence the distributions of opportunistic species across broad areas (Igl and Johnson 1999). Land-use change (i.e., conversion of native grasslands to rangeland or hayfields) has altered the structure, species diversity, density, and biomass of these grasslands and created patch-level homogeneity within management units (Fuhlendorf and Engle 2001). The result may be all-or-nothing suitability when extreme weather affects the growth and structure of the vegetation and consequently the timing of haying or burning of these lands region-wide. Although we did not analyze annual weather patterns or the spatiotemporal variability of managed grasslands, we suspect that interactions of these factors contribute to the broad-scale movements of Henslow's Sparrows from year to year.

Nomadism is most common in species that specialize on a particular food resource or whose food occurs ephemerally (Andersson 1980, Sinclair 1984, Dean 1997), frequent in arid/ semi-arid environments (Davies 1984). Northern Harriers (Circus cyaneus, Martin 1989), Boreal Owls (Aegolius funereus, Korpimäki et al. 1987), and Short-eared Owls (Asio flammeus, Korpimaki and Norrdahl 1991) feed on microtine rodents whose populations fluctuate cyclically or randomly; White Ibises (Eudocimus albus) track emergence of invertebrates from shallow and ephemeral wetlands (Frederick and Ogden 1997). We believe that Henslow's Sparrows are unusual in that their nomadism may be associated solely with the spatial and temporal patchiness of suitable breeding area related directly to structural characteristics of the vegetation, not to distribution of food resources. Grassland sparrows, including the species analyzed, feed primarily on insects during the breeding season (Wheelwright and Rising 1993, Vickery 1996, Herkert et al. 2002). Because this resource is typically superabundant (Wiens 1974, Rotenberry and Wiens 1980) and shared among the species, it is not likely a cause Henslow's Sparrow's nomadism. Instead, Henslow's Sparrows appear to be tracking disturbance cycling across the landscape (Dornak 2010), essentially moving among resource "hot spots" (Cody 1985), characterized by patches that have been idle or only lightly disturbed in $\geq 2$ years 
(Powell 2006). We are unaware of other species nomadic for reasons not related directly or indirectly to the distribution and availability of food resources.

Why then, in our study area, are Henslow's Sparrows nomadic but Grasshopper and Savannah sparrows are not? We attribute this contrast to the species' differences in breadth of preferred habitat. Grasshopper and Savannah sparrows, which do use native prairies, also exploit grazed, cultivated, or hayed fields, even occupying shrubby areas and marshes in portions of their ranges (Graber 1968, Owens and Myers 1973, Vickery 1996, Dale et al. 1997). These species tolerate more divergence from pristine grassland, as well as different (particularly earlier) stages of grassland succession, such that they can take advantage of more recently disturbed areas. Nomadism may be energetically expensive and result in delayed nesting, and even nest failure, should individuals not find suitable sites. For species with broader habitat preferences, like those of Grasshopper and Savannah sparrows, philopatry is advantageous, as familiarity with an area increases the probability of finding food, defending a territory from conspecifics, and avoiding predators (Hinde 1956). It should not be surprising then, that the prevalences of these species are greater than that of Henslow's Sparrows.

The support for nomadism in Henslow's Sparrows is strong. We believe it unlikely that the patterns we present reflect other phenomena, such as population cycling, rather than low permanence and mobile populations. Population cycling is the regular fluctuation of populations on multi-year cycles, best documented in microtine rodents; predators that specialize on them become synchronized with these cycles (Lack 1954, Ims and Steen 1990). These cycles are regulated by food and nutrient variability (Lack 1954, Batzli and Pitelka 1971) and predator-prey interactions (Lack 1954). Although population cycling could be represented as low prevalence, it is not an adequate explanation for the patterns we observed. First, as noted above, food resources are not highly variable but superabundant (Wiens 1974, Rotenberry and Wiens 1980). Second, for predation to regulate Henslow's Sparrow populations, (1) the species should have specialized predators, which it does not; it is preyed upon by generalist, opportunistic species (Wray et al. 1982, Pietz and Granfors 2000), or (2) its populations should reach peak densities (Lack 1954), which they have not over the period of available data (Sauer et al. 2011). What is more, those predators that do commonly parasitize or depredate grassland ground-nesting birds are more common and have a greater effect on species that nest nearer edges. Henslow's Sparrows select for sites away from edges and thus are less affected by predation and nest parasitism (Herkert 1994a, Pruitt 1996, Winter et al. 2000). Third, other factors shown to regulate populations in cycling species, such as disease outbreaks or density-dependent crashes, have never been recorded in Henslow's Sparrows. Fourth, if Henslow's Sparrow populations do cycle, over the years, the BBS would show both positive and negative trends; instead, it suggests small declines to somewhat stable populations (Sauer et al. 2011).

\section{CAVEATS}

Our results may have been influenced by several factors. First, the sample of the broadest resolution $\left(510000 \mathrm{~km}^{2}\right)$ was very small $(n=4)$, which likely influenced both determination of true variation in abundance and strength of hypothesis testing at that extent. Moreover, variation in abundance of both Grasshopper and Henslow's sparrows peaked at $126000 \mathrm{~km}^{2}$. These values surely contributed to differences found in both between-resolution and scale-independent analyses; it is unknown whether these values are random artifacts of smaller samples sizes or imperfect detection (Royle et al. 2005) or whether they truly represent patterns at these resolutions, since we found no such spike in Savannah Sparrows.

On the basis of results of previous analyses (Dornak 2010), some biases inherent in the BBS (change of observer, geographic influences, and nonconsecutive years) were addressed within our methods. However, certain factors, such as detectability, differences in abundance, and observers' ability to sample grassland habitats, may affect population comparisons based on observational data. Henslow's Sparrows are visually and behaviorally cryptic (Hyde 1939), which may impair detection. When they are not singing, they are difficult or impossible to detect. When they do sing, however, they perch atop vegetation, and their songs - although short and insectlike (Hyde 1939) — carry across the grassland over distances of at least $150 \mathrm{~m}$ (pers. obs.); therefore, detections based on song alone may not be a limiting factor with Henslow's Sparrows. Still, the species may not be recorded consistently because the 3 min at each BBS stop may not be long enough to encompass the singing of all males present at that stop (Diefenbach et al. 2007). This factor along with a possible decline in frequency of singing after mates pair (Leftwich and Ritchison 2000), may make Henslow's Sparrows difficult to detect, especially since BBS routes in Henslow's Sparrow's range are surveyed in June, after pair bonds have formed (Sauer et al. 2011). To assuage these concerns, we rarefied the data sets for Grasshopper and Savannah sparrow occurrences to mimic abundances and detectability of Henslow's Sparrows, then used these subsampled data sets to test for biases within our analyses. Differences in abundance and detection are similar population phenomena - even if low detectability implies more individuals present, we see no reason why those individuals would be detected with a clumped spatial structure. Hence our rarefaction mimicked both lower numbers of individuals and lower detectability, yet differences among species were still apparent. Reducing the data sets did lower the prevalence curves of Grasshopper and Savannah sparrows, but not sufficiently to change the results of the cross-scale analysis. We thus conclude that differences of detectability and abundance between these species did not bias the qualitative results of our analyses. 
A final consideration is that all BBS routes are located along roads. Forman et al. (2002) found that grassland birds avoid habitat adjacent to roads with heavy traffic. However, these findings were specific to roads with $>15000$ vehicles per day. BBS routes, on the other hand, are generally located along rural roads with light traffic (Sauer et al. 2011), which are less likely to inhibit either the observers' ability to hear singing males or the sparrows' use of habitat near the fence line (pers. obs.). Henslow's Sparrows, however, may avoid roadsides if fence lines are heavy with woody vegetation, since it decreases the habitat's attractiveness, exacerbating any detection problems (Patten et al. 2006).

\section{CONSERVATION IMPLICATIONS}

Henslow's Sparrow populations have declined over much of the species' distribution (Sauer et al. 2011), apparently in response to habitat loss and fragmentation (Pruitt 1996). Some surveys have shown a recent reversal of this trend, reporting stable or increasing populations for specific states (e.g., Illinois; Herkert 2007b), in wintering populations (National Audubon Society 2002), and even distribution-wide (T. R. Cooper, pers. comm.; Sauer and Link 2011). Although these reports are promising, they do not consider substantial losses in coming years in grasslands under the Conservation Reserve Program that currently function to augment Henslow's Sparrow breeding habitat and that may be responsible for recent population recovery (Cooper 2007, Herkert 2007a, b).

A central goal of planning for conservation of Henslow's Sparrow in its breeding range is to manage grassland habitat so as to allow for sustained or growing populations (T. R. Cooper, pers. comm.). An assumption underlying this goal, however, is that the annual cycle of Henslow's Sparrow is typical of insectivorous songbirds in this region: migration to breeding range, territory selection and establishment, pair formation and nesting, and migration to winter range. If territory selection and establishment cannot be predicted consistently because of multi-scale nomadism, as in the case of Henslow's Sparrows, however, special efforts must be made to design a configuration of patches of suitable habitat that accounts for this behavior.

At finer scales, techniques such as patch rotation should be encouraged to increase patch-level heterogeneity, which may be more compatible with the species' nomadic movement. Patch rotation on a 3-year cycle limits cattle stocking to a subset of the pasture, allows for structural development of herbaceous vegetation, and restricts woody growth, all of which promote habitat suitable for breeding Henslow's Sparrows (Wiens 1969, Herker fft 1994b, Powell 2006). This management regime considers the pattern of spatial and temporal disturbance that creates the shifting mosaic and "out-of-phase" succession across patches and should support locally nomadic populations of Henslow's Sparrows (Fuhlendorf and Engle 2001, 2004). Traditionally, core areas (>800 ha) fall under "large-scale" management (Sample et al. 2003); however, we suggest that these areas need to be managed to promote patchlevel heterogeneity.

In light of the species' nomadism, at regional scales focus should be on the configuration of locally managed areas integrated across broader regions. Ideally, these efforts would create a landscape-level mosaic of moderately sized and well-dispersed habitat patches and would buffer the effects of extreme weather. This configuration should help to support regionally nomadic populations that do not nest consistently within core areas. What is more, broad-scale management for Henslow's Sparrows that incorporates this mosaic of shifting patches will benefit species that use other phases of grassland succession. Fuhlendorf and Engle (2001) suggested that species that use remarkably different habitat co-occur across the grasslands thanks to the habitat's temporal and spatial heterogeneity. We suspect that this management regime would have far-reaching, positive effects on avian diversity in North American grasslands. For management at this scale to be implemented efficiently and with limited financial costs and wasted effort, detailed and dynamic maps of suitable breeding habitat across Henslow's Sparrow's full distribution will be necessary, maps that will have to take local landscape dynamics into account directly.

\section{ACKNOWLEDGMENTS}

We thank S. L. Egbert for academic guidance and J. Soberón for theoretical and technical advice. We also thank David Martinez-Gordillo for the Spanish translation of the abstract. Funding was provided by the Department of Geography, Doctoral Dissertation Research Improvement Grant (Geography and Spatial Science, SBE \#1131644).

\section{LITERATURE CITED}

Ahlering, M. A., D. H. Johnson, And J. FAaborg. 2006. Conspecific attraction in a grassland bird, the Baird's Sparrow. Journal of Field Ornithology 77:365-371.

Allen, C., AND D. SAUnders. 2006. Multimodel inference and the understanding of complexity, discontinuity, and nomadism. Ecosystems 9:694-699.

Allen, C. R., And D. A. Saunders. 2002. Variability between scales: predictors of nomadism in birds of an Australian Mediterranean-climate ecosystem. Ecosystems 5:348-359.

Andersson, M. 1980. Nomadism and site tenacity as alternative reproductive tactics in birds. Journal of Animal Ecology 49:175-184.

Batzli, G. O., And F. A. PitelKa. 1971. Condition and diet of cycling populations of the California vole, Microtus californicus. Journal of Mammalogy 52:141-163.

BÉDARD, J., AND G. LAPOINTE. 1984. Banding returns, arrival times, and site fidelity in the Savannah Sparrow. Wilson Bulletin 96:196-205.

BRAGG, T. B. 1995. The physical environment of great plains grasslands, p. 49-81. In A. Joern [ED.], The changing prairie: North American grasslands. Oxford University Press, New York.

Cody, M. L. 1985. Habitat selection in open-country birds, p. 191226. In M. L. Cody [ED.], Habitat selection in birds. Academic Press, Orlando, FL. 
COOPER, T. R. 2007. Henslow's Sparrow conservation action plan workshop summary. U.S. Fish and Wildlife Service, Bloomington, IN.

Dale, B. C., P. A. Martin, AND P. S. TAYlor. 1997. Effects of hay management on grassland songbirds in Saskatchewan. Wildlife Society Bulletin 25:616-626.

DAVIES, S. J. J. F. 1984. Nomadism as a response to desert conditions in Australia. Journal of Arid Environments 7:183-195.

DEAN, W. R. J. 1997. The distribution and biology of nomadic birds in the Karoo, South Africa. Journal of Biogeography 24:769-779.

Diefenbach, D. R., M. R. Marshall, J. A. Mattice, and D. BraunING. 2007. Incorporating availability for detection in estimates of bird abundance. Auk 124:96-106.

Dorfman, E. J., AND R. T. Kingsford. 2001. Scale-dependent patterns of abundance and habitat use by cormorants in arid Australia and the importance of nomadism. Journal of Arid Environments 49:677-694.

DornaK, L. L. 2010. Breeding patterns of Henslow's Sparrow and sympatric grassland sparrow species. Wilson Journal of Ornithology 122:635-645.

Forman, R. T. T., B. Reineking, and A. M. Hersperger. 2002. Road traffic and nearby grassland bird patterns in a suburbanizing landscape. Environmental Management 29:782-800.

Frederick, P. C., AND J. C. OGden. 1997. Philopatry and nomadism: contrasting long-term movement behavior and population dynamics of White Ibises and Wood Storks. Colonial Waterbirds 20:316-323.

FUhlENDORF, S. D., AND D. M. ENGLE. 2001. Restoring heterogeneity on rangelands: ecosystem management based on evolutionary grazing patterns. BioScience 51:625-632.

Fuhlendorf, S. D., AND D. M. ENGLE. 2004. Application of the firegrazing interaction to restore a shifting mosaic on tallgrass prairie. Journal of Applied Ecology 41:604-614.

Graber, J. W. 1968. Passerherbulus henslowii henslowii (Audubon): Western Henslow's Sparrow, p. 237. In O. L. Austin [ED.], Life histories of North American cardinals, grosbeaks, buntings, towhees, finches, sparrows, and allies. U.S. National Museum Bulletin 237.

Greenwood, P. J., And P. H. Harvey. 1982. The natal and breeding dispersal of birds. Annual Review of Ecology and Systematics 13:1-21.

Harvey, P. H., P. J. Greenwood, and C. M. Perrins. 1979. Breeding area fidelity of Great Tits (Parus major). Journal of Animal Ecology 48:305-313.

Herkert, J. R. 1994a. The effects of habitat fragmentation on Midwestern grassland bird communities. Ecological Applications 4:461-471.

HERKERT, J. R. 1994b. Status and habitat selection of the Henslow's Sparrow in Illinois. Wilson Bulletin 106:35-45.

Herkert, J. R. 2007a. Evidence for a recent Henslow's Sparrow population increase in Illinois. Journal of Wildlife Management 71:1229-1233.

Herkert, J. R. 2007b. Conservation Reserve Program benefits on Henslow's Sparrows within the United States. Journal of Wildlife Management 71:2750-2751.

Herkert, J. R., AND W. D. GLASS. 1999. Henslow's Sparrow response to prescribed fire in an Illinois prairie remnant. Studies in Avian Biology 19:160-164.

Herkert, J. R., D. W. Sample, and R. E. Warner. 1996. Management of Midwestern grassland landscapes for the conservation of migratory birds, p. 89-116. In F. R. Thompson [ED.], Management of Midwestern landscapes for the conservation of neotropical migratory birds. . U.S. Forest Service General Technical Report NC-187.
Herkert, J. R., P. D. Vickery, AND D. E. Kroodsma. 2002. Henslow's Sparrow (Ammodramus henslowii), no 672. In A. Poole and F. Gill [EDS.], The birds of North America. Birds of North America, Inc., Philadelphia.

Hinde, R. A. 1956. The biological significance of the territories of birds. Ibis 98:340-369.

Hyde, A. S. 1939. The life history of Henslow's Sparrow, Passerherbulus henslowi (Audubon). Museum of Zoology, University of Michigan, Miscellaneous Publications 41:1-79.

IgL, L. D., AND D. H. Johnson. 1999. Le Conte's Sparrows breeding range in Conservation Reserve Program fields: precipitation and patterns of population change. Studies in Avian Biology 19:178-186.

Ims, R. A., AND H. SteEn. 1990. Geographical synchrony in microtine population cycles: a theoretical evaluation of the role of nomadic avian predators. Oikos 57:381-387.

Johnson, D. H., AND J. W. GRIER. 1988. Determinants of breeding distributions of ducks. Wildlife Monographs 100:3-37.

Jones, S. L., J. S. Dieni, M. T. Green, And P. J. Gouse. 2007. Annual return rates of breeding grassland songbirds. Wilson Journal of Ornithology 119:89-94.

Kantrud, H. A., And C. A. Fannes. 1979. Range expansion of Baird's Sparrow in South Dakota. Prairie Naturalist 11:111-112.

KorpimäKi, E., M. Lagerström, And P. SaUrola. 1987. Field evidence for nomadism in Tengmalm's Owl Aegolius funereus. Ornis Scandinavica 18:1-4.

KorPIMÄKI, E., AND K. NORRDAHL. 1991. Numerical and functional responses of kestrels, Short-eared Owls, and Long-eared Owls to vole densities. Ecology 72:814-826.

LACK, D. 1954. Cyclic mortality. Journal of Wildlife Management $18: 25-37$.

Leftwich, C., And G. Ritchison. 2000. Singing behavior of male Henslow's Sparrows (Ammodramus henslowii). Bird Behavior 18:1-7.

Martin, J. W. 1989. Harriers and kites, p. 92-101. In B. G. Pendleton [ED.], Proceedings of the western raptor management symposium and workshop. National Wildlife Federation Scientific Technical Series, Washington, D.C.

Milton, S. J., W. R. J. Dean, M. A. Du Plessis, and W. R. Siegfried. 1994. A conceptual model of arid rangeland degradation. BioScience 44:70-76.

National Audubon Society [ONLINE]. 2002. The Christmas bird count historical results. <http://www.audubon.org/bird/cbc> (15 December 2011).

Newton, I., AND M. Marquiss. 1982. Fidelity to breeding area and mate in Sparrowhawks Accipiter nisus. Journal of Animal Ecology 51:327-341.

Owens, R. A., AND M. T. Myers. 1973. Effects of agriculture upon populations of native passerine birds of an Alberta fescue grassland. Canadian Journal of Zoology 51:697-713.

Patten, M. A., E. Shochat, D. L. Reinking, D. H. Wolfe, and S. K. SHERROD. 2006. Habitat edge, land management, and rates of brood parasitism in tallgrass prairie. Ecological Applications 16:687-695.

Pietz, P. J., AND D. A. Granfors. 2000. Identifying predators and fates of grassland passerine nests using miniature video cameras. Journal of Wildlife Management 64:71-87.

Powell, A. F. L. A. 2006. Effects of prescribed burns and bison (Bos bison) grazing on breeding bird abundances in tallgrass prairie. Auk 123:183-197.

PRUITT, L. 1996. Henslow's Sparrow: status assessment. Department of the Interior, U.S. Fish and Wildlife Service, Bloomington, IN.

R Development Core Team. 2011. R: A language and environment for statistical computing. R Foundation for Statistical Computing, Vienna. 
Robbins, M. B., A. T. Peterson, And M. A. Ortega-Huerta. 2002. Major negative impacts of early intensive cattle stocking on tallgrass prairies: the case of the Greater Prairie-Chicken (Tympanuchus cupido). North American Birds 56:239-244.

RotenberRy, J. T., AND J. A. WIENs. 1980. Habitat structure, patchiness, and avian communities in North American steppe vegetation: a multivariate analysis. Ecology 61:1228-1250.

Royle, J. A., J. D. NichOls, AND M. KÉRY. 2005. Modelling occurrence and abundance of species when detection is imperfect. Oikos 110:353-359.

Sample, D. W., C. A. Ribic, And R. B. Renfrew. 2003. Linking landscape management with the conservation of grassland birds in Wisconsin, p. 359-385. In J. A. Bissonette and I. Storch [EDS.], Landscape ecology and resource management: linking theory with practice. Island Press, Washington, D.C.

Sauer, J. R., J. E. Hines, J. E. Fallon, K. L. Pardieck, D. J. Ziolkowski JR., AND W. A. Link. 2011. The North American Breeding Bird Survey, results and analysis 1966-2010, version 12.07.2011. Patuxent Wildlife Research Center, Laurel, MD.

SAUER, J. R., AND W. A. Link. 2011. Analysis of the North American Breeding Bird Survey using hierarchical models Auk 128:87-98.

SinclaiR,, A. R. E. 1984. The function of distance movement in vertebrates, p. 240-258. In I. R. Swingland and P. J. Greenwood [EDS.], The ecology of animal movement. Clarendon Press, Oxford, England.

Skipper, C. S. 1998. Henslow's Sparrows return to previous nest site in western Maryland. North American Bird Bander 23:36-41.

SPSS INSTITUTE. 2008. SPSS for Windows, version 16.0. SPSS Institute, Inc., Chicago.
STAMPS, J. A. 1987. Conspecifics as cues to territory quality: a preference of juvenile lizards (Anolis aeneus) for previously used territories. American Naturalist 129:629-642.

STAMPS, J. A. 1988. Conspecific attraction and aggregation in territorial species. American Naturalist 131:329-347.

Swengel, S. R. 1996. Management responses of three species of declining sparrows in tallgrass prairie. Bird Conservation International 6:241-253.

ViCKeRY, P. D. 1996. Grasshopper Sparrow, no. 239. In A. Poole and F. Gill [EDS.], The birds of North America. Academy of Natural Sciences, Philadelphia.

Vickery, P. D., P. Tubaro, J. M. Cardoso da Silva, B. G. PeterJOHN, J. R. HERKERT, AND R. B. CaVAlCANTI. 1999. Conservation of grassland birds in the Western Hemisphere. Studies in Avian Biology 19:2-26.

WheELwRIGHT, N. T., AND J. D. Rising. 1993. Savannah Sparrow, no. 45. In A. Poole and F. Gill [EDS.], The birds of North America. Academy of Natural Sciences, Philadelphia.

WIENS, J. A. 1969. An approach to the study of ecological relationships among grassland birds. Ornithological Monographs 8:1-93.

WIENS, J. A. 1974. Climatic instability and the "ecological saturation" of bird communities in North American grasslands. Condor 76:385-400.

WIENS, J. A. 1986. Spatial scale and temporal variation in studies of shrubsteppe birds, p. 154-172. In J. M. Diamond and T. J. Case [EDS.], Community ecology. Harper and Row, New York.

WinTER, M., D. H. JOHNSON, AND J. FAABORG. 2000. Evidence for edge effects on multiple levels in tallgrass prairie. Condor 102:256-266.

Wray, T. II, K. A. Strait, And R. C. Whitmore. 1982. Reproductive success of grassland sparrows on a reclaimed surface mine in West Virginia. Auk 99:157-164. 